\title{
Heroin Abuse and Myocardial Infarction
}

\author{
Eroin Kullanımı ve Miyokard İnfarktüsï \\ Ersan TATLI, Meryem AKTOZ \\ Department of Cardiology, Medical Faculty of Trakya University, Edirne
}

Submitted / Başvuru tarihi: 23.08.2008 Accepted / Kabul tarihi: 25.10.2008

\begin{abstract}
Information concerning acute myocardial infarction after heroin usage is limited and the actual mechanism of heroin-induced myocardial infarction is not well known. Only one report has been described noting the association between usage heroin and acute myocardial infarction in a young man with normal coronary arteries. We also reported a patient with normal coronary arteries and acute myocardial infarction after heroin abuse.
\end{abstract}

Key words: Heroin usage; acute myocardial infarction.
Eroin kullanımı sonrası akut miyokard infarktüsü ile ilişkili bilgiler sınırlıdır ve eroinin tetiklediği akut miyokard infarktüsünün mekanizması tam olarak bilinmemektedir. Eroin kullanımıyla ilişkili akut miyokard infarktüsü gelişen normal koroner arterlere sahip sadece bir olgu şimdiye kadar rapor edilmiştir. Biz de eroin kulanımı sonrası miyokard infarktüsü gelişen normal koroner arterlere sahip bir olgu rapor ettik.

Anahtar sözcükler: Eroin kullanımı; akut miyokard infarktüsü.
Heroin use has increased dramatically throughout the world during the past decade. Information concerning acute myocardial infarction after heroin usage is limited and the actual mechanism of heroin-induced myocardial infarction is not well known. Yu et al. ${ }^{[1]}$ reported the first case of acute myocardial infarction associated with heroin abuse and the patient's coronary angiography showed normal coronary angiograms. Most acute myocardial infarction patients in previous reports had significant coronary stenosis. ${ }^{[2-4]}$ We reported a patient with normal coronary arteries and acute myocardial infarction after heroin abuse.

\section{CASE REPORT}

A 31-year-old man was admitted to our clinic with a complain of chest pain lasting about $90 \mathrm{~min}$. He has smoked about one package of cigarettes daily and consumed inhaled heroin during weekends (the last consumption of heroin was two hours ago). His past medical history and laboratory examination revealed no coronary risk factors. Initial electrocardiogram showed sinus rhythm and ST segment elevation in inferior leads (Fig. 1). Creatine-kinase isoenzyme MB and troponin I were elevated. The patient was immediately taken to coronary care unit because of acute inferior myocardial infarction. Intravenous heparin, nitroglycerin and antiaggregant (75 mg clopidogrel and $300 \mathrm{mg}$ acetylsalysylic acid) were administered promptly. Coronary angiography showed normal coronary angiograms in the second day (Figs. 2, 3). He was discharged five days after the acute myocardial infarction episode. A follow-up echocardiography showed normal heart chamber size and wall motion after two months.

\section{DISCUSSION}

Information concerning acute myocardial infarction after heroin usage is limited. The medical literature contains two cases of acute myocardial infarction after usage heroin. The first case was a 25-year-old woman who developed acute myocardial infarction after heroin usage; her 
coronary angiography revealed a coronary occlusion in the left anterior descending coronary artery. ${ }^{[2]}$ The second case was a 38-year-old man who developed acute myocardial infarction after heroin injection; his coronary angiography was normal. ${ }^{[1]}$ We wanted to emphasize that the risk of acute myocardial infarction elevated after heroin usage, and heroin could cause coronary vasospasm in this case.

Patients with heroin-related infarction are young, male and heavy smokers but without other risk factors for atherosclerosis. ${ }^{[1,2]}$ The actual mechanism of heroin-induced myocardial infarction is not well known. Animal studies have found that the heroin might have a systemic effect or direct toxicity to the heart. ${ }^{[5,6]}$ The hypothesis of heroin-related infarction is multifactorial and includes an increased myocardial oxygen demand, marked vasoconstriction of the coronary arteries, acidosis or hypersensitivity reactions associated with heroin. ${ }^{[7]}$

Sztajzel et al. ${ }^{[2]}$ claimed that heroin might have a direct toxic effect on the coronary arteries and induce acute coronary occlusion, either by provoking a local coronary spasm or inflammation.

Heroin affects directly on the vasomotor center, so it increases parasympathetic activity, reduces sympathetic tone, and stimulates the release of histamine from mast cells. ${ }^{[8]}$ Enhanced parasympathetic activity also plays a role in the initation of coronary spasm. ${ }^{[9]}$ Our patient was only 31 years old and did not have other risk factors except smoking; coronary atherosclerosis was unlikely to be the cause of acute myocardial infarction in our patient. Due to his history of chest tightness and pain after sniffing heroin, a heroin-induced acute myocardial infarction seems to be a reasonable diagnosis for this patient. The cause of his infarction episode is highly suspected to be the heroin-induced toxic effect and/or coronary spasm.

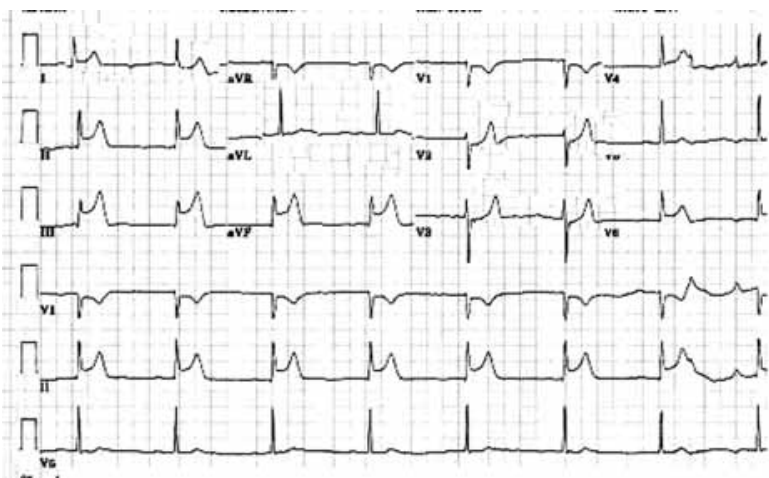

Fig. 1. Electrocardiogram showed sinus rhythm and ST segment elevation in inferior leads.

In conclusion, it is important to identify patients with heroin-related acute myocardial infarction because the diagnostic and treatment approaches are different from the patient with atherosclerosis heart disease. Therefore, heroin usage should be added to traditional epidemiological history particularly in young patients complaining of acute chest pain.

\section{REFERENCES}

1. Yu SL, Liu CP, Lo YK, Lin SL. Acute myocardial infarction after heroin injections. Jpn Heart J 2004;45:1021-8.

2. Sztajzel J, Karpuz H, Rutishauser W. Heroin abuse and myocardial infarction. Int J Cardiol 1994;47:180-2.

3. Auer J, Punzengruber C, Berent R, Weber T, Eber B. Multiple complex coronary plaques in a patient with acute myocardial infarction. Heart Vessels 2002;16:211-3.

4. Hosokawa S, Hiasa Y, Miyamoto H, Suzuki N, Takahashi $\mathrm{T}$, Kishi $\mathrm{K}$, et al. Acute myocardial infarction showing total occlusion of right coronary artery and thrombus formation of left anterior descending artery. Jpn Heart J 2001;42:365-9.

5. Paterna S, Di Pasquale P, Montaina G, Procaccianti P, Antona A, Scaglione R, et al. Effect of heroin and morphine on cardiac performance in isolated and perfused rabbit heart: evaluation of cardiac haemodynamics, myocardial enzyme activity and ultrastructure features. Cardiologia 1991;36:811-5.
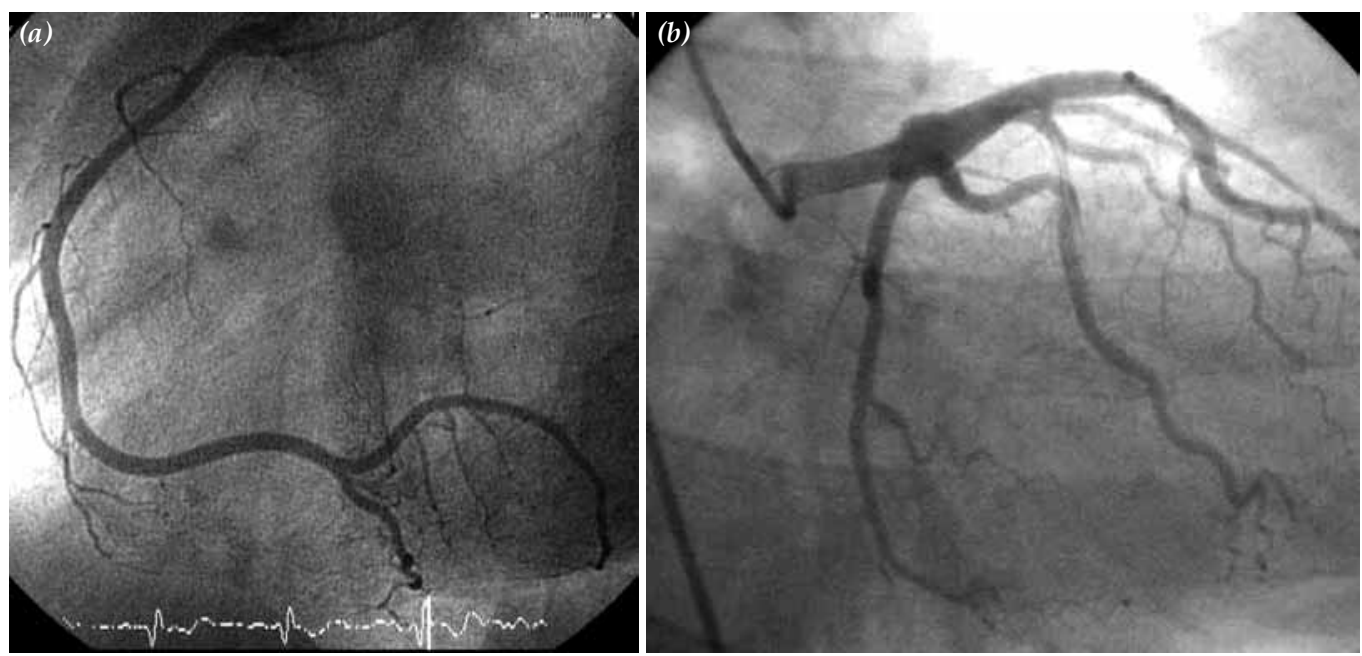

Fig. 2. Coronary angiography showed (a) normal right coronary artery, (b) normal left anterior descending and circumflex coronary artery. 
6. Schwartzfarb L, Singh G, Marcus D. Heroin-associated rhabdomyolysis with cardiac involvement. Arch Intern Med 1977;137:1255-7.

7. Melandri R, De Tommaso I, Zele I, Rizzoli D, Rapezzi C, Pezzilli R, et al. Myocardial involvement in rhabdomyolysis caused by acute heroin intoxication. [Article in Italian]
Recenti Prog Med 1991;82:324-7. [Abstract]

8. Schwartz RH. Adolescent heroin use: a review. Pediatrics 1998;102:1461-6.

9. Suematsu M, Ito $Y$, Fukuzaki $H$. The role of parasympathetic nerve activity in the pathogenesis of coronary vasospasm. Jpn Heart J 1987;28:649-61. 